\title{
Battleground Energy Recovery Project
}

\author{
DOE Award \#DE-EE0002028 \\ March 30, 2012
}

FINAL REPORT

For the period October 1, 2009 through December 31, 2011

\author{
$\underline{\text { Recipient }}$ \\ Houston Advanced Research Center
}

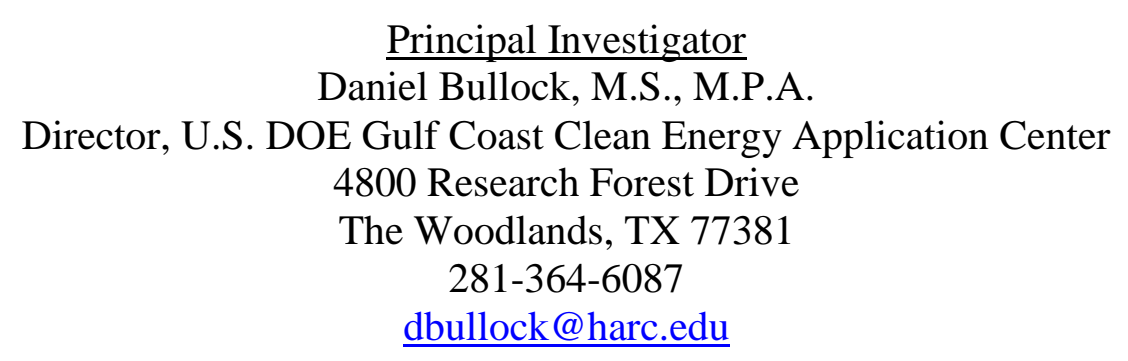




\section{TABLE OF CONTENTS}

CHAPTER 1: Introduction

CHAPTER 2: Power Sale with Steam Sale to TOTAL Petrochemical

CHAPTER 3: Power Sale with Steam Sale to Dow Chemical

CHAPTER 4: Power Sale Only

CHAPTER 5: Engineer/Procure/Construct (EPC)

CHAPTER 6: Archeological Study

CHAPTER 7: Lessons Learned

\section{"DISCLAIMER}

This report was prepared as an account of work sponsored by an agency of the United States Government. Neither the United States Government nor any agency thereof, nor any of their employees, makes any warranty, express or implied, or assumes any legal liability or responsibility for the accuracy, completeness, or usefulness of any information, apparatus, product, or process disclosed, or represents that its use would not infringe privately owned rights. Reference herein to any specific commercial product, process, or service by trade name, trademark, manufacturer, or otherwise does not necessarily constitute or imply its endorsement, recommendation, or favoring by the United States Government or any agency thereof. The views and opinions of authors expressed herein do not necessarily state or reflect those of the United States Government or any agency thereof." 


\section{BATTLEGROUND ENERGY RECOVERY PROJECT FINAL REPORT}

\section{Chapter 1: Introduction}

In October 2009, the project partners began a 36-month effort to develop an innovative, commercial-scale demonstration project incorporating state-of-the-art waste heat recovery technology at Clean Harbors, Inc., a large hazardous waste incinerator site located in Deer Park, Texas. With financial support provided by the U.S. Department of Energy, the Battleground Energy Recovery Project was launched to advance waste heat recovery solutions into the hazardous waste incineration market, an area that has seen little adoption of heat recovery in the United States. The goal of the project was to accelerate the use of energy-efficient, waste heat recovery technology as an alternative means to produce steam for industrial processes.

The original project partners included the following four organizations:

- Houston Advanced Research Center - a non-profit scientific institution dedicated to improving human and ecosystem well-being through the application of sustainability science and principles of sustainable development

- Integral Power, LLC - a waste heat and opportunity fuel project developer

- Clean Harbors, Inc. - a leading provider of environmental and hazardous waste management services

- TOTAL Petrochemicals USA, Inc. -- a worldwide producer of base chemicals and fuels

The project entailed implementation of the waste heat recovery boiler at the Clean Harbors incinerator in Deer Park, Texas. Clean Harbors has a high temperature flue gas exiting their incinerator, but the company is quenching it with water at a rate of about 500 gallons per minute to achieve a temperature low enough for downstream pollution control equipment. The project involved constructing a waste heat recovery boiler into the existing process train at Clean Harbors to generate steam, thereby capturing wasted energy and substantially reducing water used in the quench process.

Steam generated by the project was to be used for the production of electricity using a conventional Rankin Cycle or to augment the steam supply at the TOTAL polypropylene plant, thereby reducing natural gas consumption in their existing boilers currently being used to produce steam. The project would have reduced natural gas consumption at the TOTAL plant and met the majority of the electrical consumption of the Clean Harbors facility with zero emission electricity. The project was expected to reduce overall emissions of NOx and CO2 in the Houston-Galveston-Brazoria non-attainment zone. The project was also expected to dramatically reduce the amount of quench water used by Clean Harbors. Because the project was expected to reduce the operating costs for both TOTAL and Clean Harbors' plants, the project would have increased the competiveness of local industry and protected local jobs. 


\section{$\mathbf{A}|\mathbf{H}| \mathbf{A}|\mathbf{R}| \mathbf{C} \mid \boldsymbol{|}$}

Final Report

Battleground Energy Recovery Project

October 1, 2009 - December 31, 2011

The project had three main engineering and business objectives:

- $\quad$ Prove Feasibility of Waste Heat Recovery Technology at a Hazardous Waste Incinerator

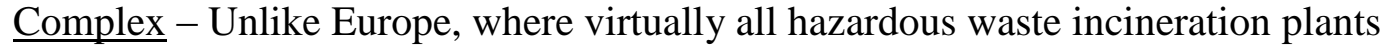
include waste heat recovery in their design, practically no U.S. hazardous waste incineration plants currently have waste heat recovery in operation. The Battleground Energy Recovery Project was to create reliable U.S. engineering design standards for using waste heat recovery boilers in this most difficult flue gas service.

- $\quad$ Provide Low-cost Steam to a Major Polypropylene Plant Using Waste Heat - the project was to provide over 100,000 lbs per hour of steam to the nation's largest polypropylene manufacturing plant, thereby demonstrating commercial scale steam energy production without natural gas and with zero net emissions. The project was to reduce the cost of energy for the plant, thereby improving long-term profitability and protecting jobs.

- Create a Showcase Waste Heat Recovery Demonstration Project - the Battleground Energy Recovery Project was to provide a showcase demonstration site for viable waste heat recovery in the hazardous waste incinerator application. A showcase project is critical to spur development of additional projects at similar and related facilities.

\section{$\underline{\text { Background }}$}

Clean Harbors Environmental Services (Clean Harbors) operates a commercial hazardous waste incineration facility in Deer Park, Texas. The Deer Park facility includes two (2) RCRA kilns with state-of-the-art downstream emission control equipment, and is considered BACT for emission control in the hazardous waste incineration industry. Integral Power, LLC (IP) signed a Memorandum-of-Intent with Clean Harbors on October 29, 2007 to develop a waste heat recovery project at the Deer Park plant by recovering energy from the high temperature flue gas that exhausts from two kiln afterburners existing at the plant. Presently, the two kiln afterburners exhaust at $2,100^{\circ} \mathrm{F}$, and this temperature is "quenched" to $350^{\circ} \mathrm{F}$ with water sprays to match the temperature limitations of the downstream emission control equipment. Once the project is completed, this $2,100^{\circ} \mathrm{F}$ flue gas would have been diverted to waste heat boilers, converting this opportunity fuel (flue gas waste heat) into useful steam and or power.

Through investigation with neighboring facilities, Integral Power found that the thermal energy available in Clean Harbors' Unit 1 kiln/afterburner system closely matched the steam energy required by neighboring TOTAL Petrochemicals, which utilizes 100 psig saturated steam in the production of polypropylene. Due to the excellent match between the Unit 1 heat availability and the steam load at the TOTAL plant, the original project as conceived was to primarily entail steam deliveries to TOTAL, with electricity production occurring during times of slack steam demand or as economics dictated due to price fluctuations over time.

Natural Gas Price Volatility

The original proposal to U.S. DOE was submitted in July, 2008 when the price of natural gas at the Henry Hub was over $\$ 12 /$ MMBtu. Shortly thereafter, the price of natural gas fell dramatically to under $\$ 4 / \mathrm{MMBtu}$ within six months. The natural gas market dynamics at the time of project initiation are shown in the Figure below. 


\section{$\mathbf{1}|\mathbf{H}| \mathbf{A}|\mathbf{R}| \mathbf{C} \mid \boldsymbol{H}$}

Battleground Energy Recovery Project

Final Report

October 1, 2009 - December 31, 2011

As a result of the precipitous decline in natural gas prices, the strong economics driving the project were severely diminished. The value of steam sales envisioned to TOTAL fell by over $80 \%$, while the value of electricity fell in kind, as wholesale power pricing in ERCOT is tied to the economics of gas-fired generation operating on the margin. Consequently, revenues expected from energy sales from the project were unable to meet the project's capital requirement and still provide sufficiently high returns to equity investors. As a result, the development team's ability to finance the project was diminished.

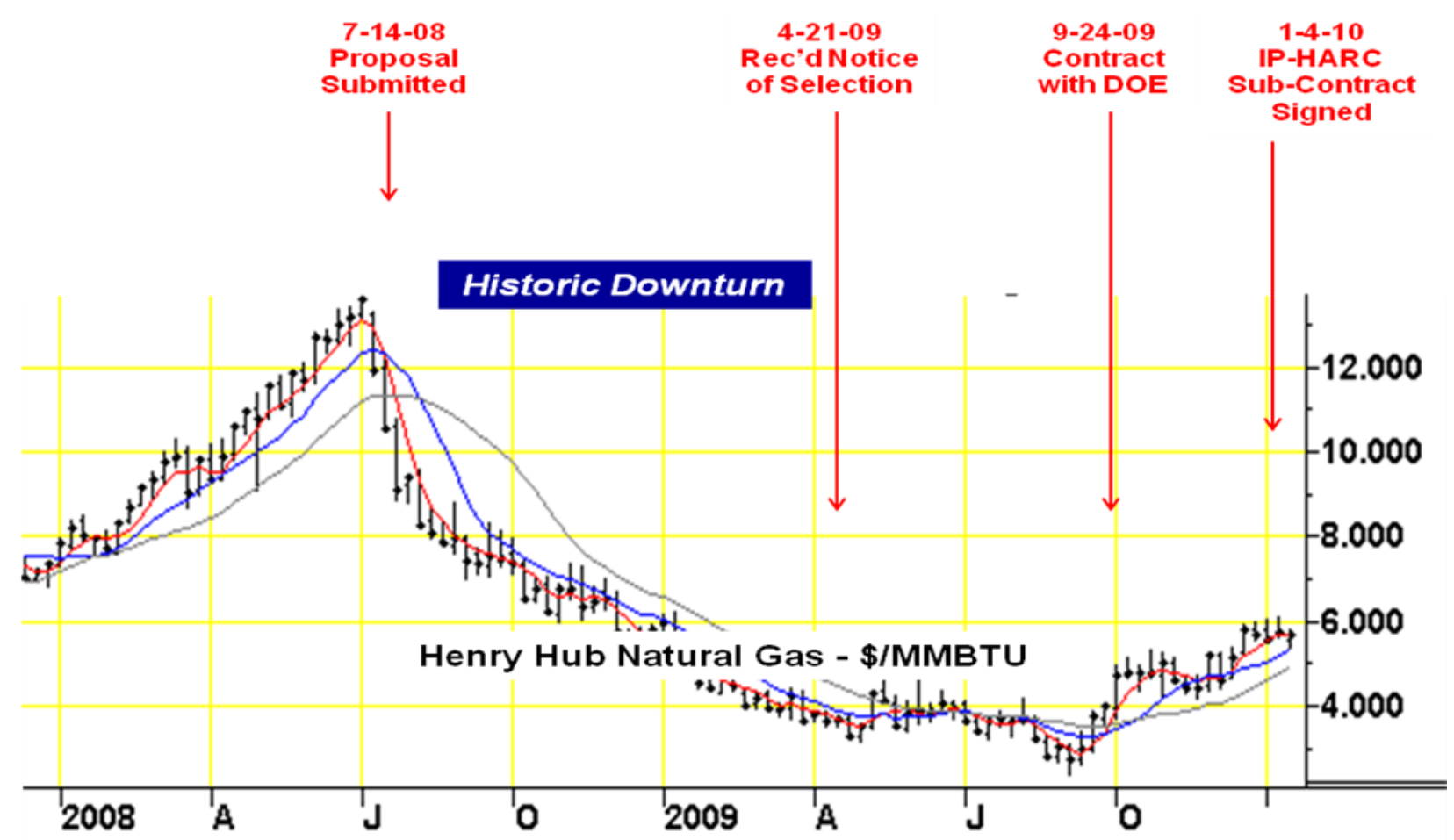

Throughout the project period, the team actively looked at and evaluated numerous alternative project scenarios, while waiting for the price of natural gas to rise to a price more consistent with the long term price relationship with oil. In the three years from Jan 2009 to December 2011, the team worked to develop one of three cases thought to offer the best prospects for a successful project, while waiting for gas prices to recover. The three cases included:

- Case 1: Power sale and steam sale to Total Petrochemical

- Case 2: Power sale and steam sale to Dow Chemical

- Case 3: Power sale only

What was under appreciated at the time was how emerging shale gas production technology would radically change the fundamentals of the supply picture for natural gas. As a result, the anticipated rise in natural gas prices never materialized and today, the commodity sells for less than $\$ 2.50 /$ MMBtu. 


\section{$\underline{\text { Project Status }}$}

A comprehensive development package was completed for the Battleground Energy Recovery Project including process integration engineering, equipment design engineering, steam line layout and engineering, electrical engineering, environmental engineering, and an archeological study. Unfortunately, the project cannot be financed in the current economic climate. However, it will likely be constructed at some point in the next several years, especially if natural gas prices rise to a more normal level of \$4-5/MMBtu level or if the value of reducing water consumption or reducing carbon dioxide emissions increases in a material way. Consequently, this report documents the extensive technical analysis, engineering, and economic modeling undertaken to date. The project is now fully developed, shovel-ready, and waiting for better economic conditions.

\section{Chapter 2: Power Sale with Steam Sale to Total Petrochemical}

The original project as proposed to U.S. DOE in 2008 was to be located at the Clean Harbors incinerator facility in Deer Park, Texas. The project involved installation and operation of a waste heat recovery boiler on the Unit 1 afterburner located on the Clean Harbors hazardous waste incineration site. The boiler was to be specialized for hazardous flue gas service. The boiler was anticipated to supply a nominal output of $100,000 \mathrm{lb} / \mathrm{hr}$ steam at $275 \mathrm{psig} / 465^{\circ} \mathrm{F}$, which was to be delivered to TOTAL Petrochemical USA (TOTAL) plant through an insulated, 10-inch steam pipeline about 4,000 feet long. A similar 4,000 foot makeup water pipeline was to return condensate to the heat recovery boiler.

The heat recovery boiler located on the Unit 1 afterburner exhaust was expected to produce a nominal $100,000 \mathrm{lb} / \mathrm{hr}$ steam at $275 \mathrm{psig}$ and $465^{\circ} \mathrm{F}$. Although $100 \mathrm{psig} / \mathrm{saturated}$ steam at $338^{\circ} \mathrm{F}$ was required at TOTAL, the higher pressure and temperature conditions at the boiler was necessary to allow operation of steam soot blowers and to ensure adequate margin for losses associated with the approximate 4,000 ft steam pipeline. At the TOTAL steam header tie-in, the project would have supplied de-superheated steam at a rate of 102,000 lb/hr at $100 \mathrm{psig}$ and $338^{\circ} \mathrm{F}(1,189.7 \mathrm{BTU} / \mathrm{lb})$. The project was to supply approximately $121.3 \mathrm{MMBTU} / \mathrm{hr}$ to TOTAL on a continuous basis and at $100 \%$ efficiency (i.e., TOTAL will only pay for BTUs received through the steam meter). A natural gas boiler at $83 \%$ efficiency would require $146 \mathrm{MMBTU} / \mathrm{hr}$ of natural gas to produce the same amount of steam energy.

The Clean Harbors and TOTAL plants are located on opposite sides of Battleground Road, a heavily industrialized area of the Houston Ship Channel petrochemical corridor. Surprisingly, Battleground Road is also a Texas scenic highway leading to the San Jacinto Monument from Texas Hwy 225. For this reason, the project was referred to as the "Battleground Energy Recovery Project." An aerial view of the project site including Battleground Road and the adjacent TOTAL plant site is shown below.

\section{Operations \& Maintenance}

The new waste heat recovery boiler and associated balance of plant was to be an integral part of Clean Harbors' incineration process. The boiler was to be sited as close to the Unit 1 afterburner exhaust duct as possible to minimize the boiler duct radiant losses and cost. A major goal of the 


\section{$\mathbf{I}|\mathbf{H}| \mathbf{A}|\mathbf{R}| \mathbf{C} \mid \boldsymbol{|}$}

Battleground Energy Recovery Project

program was to effectively handle the dirty flue gas coming from the incinerator, which is known to cause caking and fouling of the heat exchangers and other components.

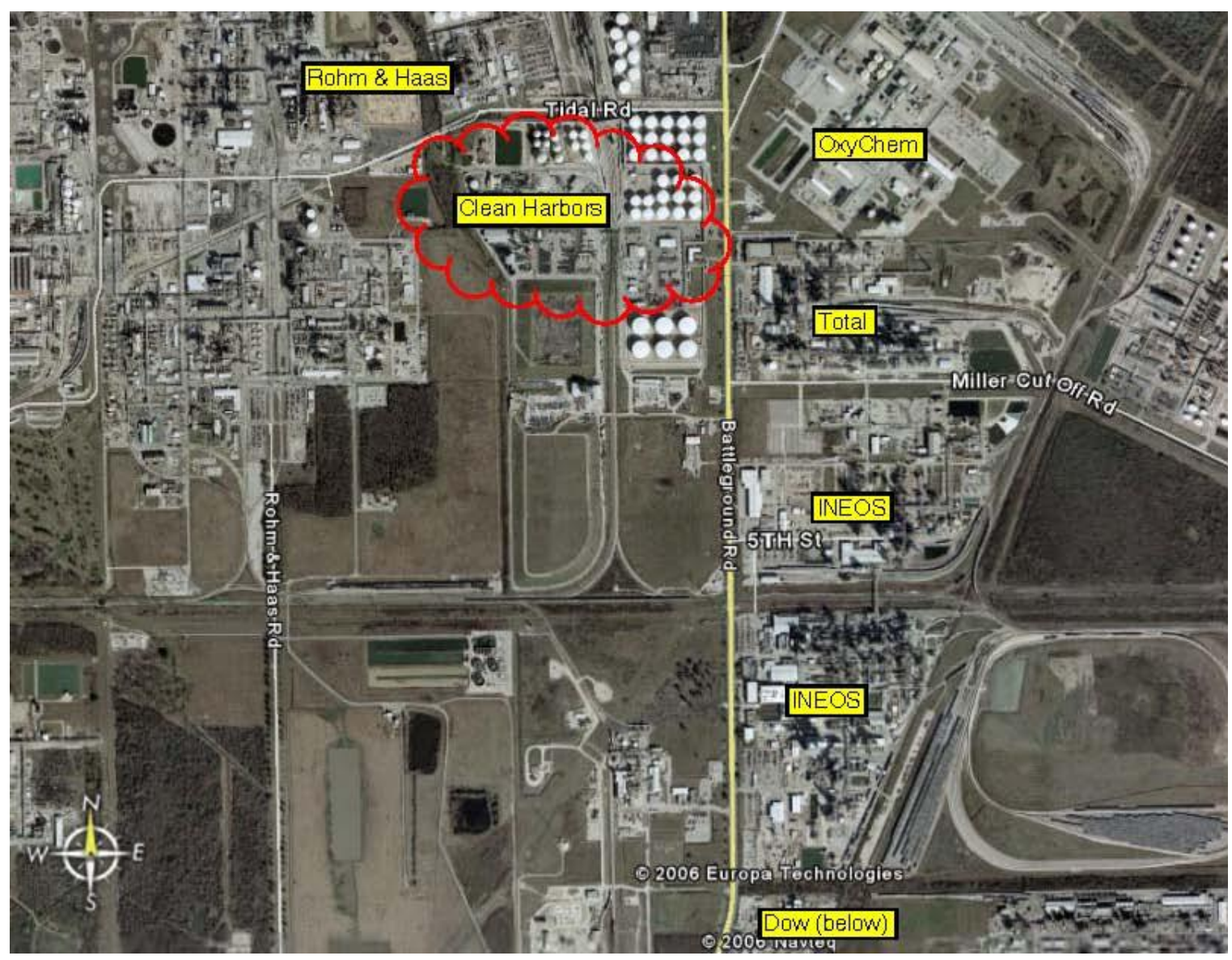

Clean Harbors was expected to operate and maintain the heat recovery equipment. This task included operating the unit as an extension of the existing incineration plant and performing O\&M largely with existing personnel. To facilitate easy, cost effective operation, the project's control system was to be integrated with the on-site controls existing at Clean Harbors, while a fiber optic link was to connect the project control system to the control room at TOTAL.

\section{Water Supply}

TOTAL Petrochemical USA currently meets its steam needs with conventional gas fired boilers, which requires softening makeup water for steam generation on their side. Because the steam supplied by the project was to be a direct offset, TOTAL had agreed to provide all required makeup water. The water supply was to be a mixture of steam condensate and softened, deaerated makeup water, which combine to approximately $210^{\circ} \mathrm{F}$. In order to preserve as much of the temperature in the hot condensate as possible, the water supply pipeline (routed along the same pipe rack as the steam pipeline) was to be insulated. Water supply was to be routed to an insulated storage tank on the Clean Harbors' side, which would have provided temporary supply capacity in the event of a water supply interruption. 


\section{Chapter 3: Power Sale with Steam Sale to Dow Chemical}

The Dow Chemical case is very similar to the TOTAL case, except that Dow Chemical replaces TOTAL as the steam host. The Clean Harbors facility shares a property line with a Dow Chemical plant, so steam sales to Dow are simplified in that they will not require the steam pipeline to cross any rights-of-way, including Battleground Road. Dow had been approached much earlier in the project, but at that time Dow had little interest in the project. However, due in part to corporate sustainability and environmental goals, the Dow alternative came back to life and was fully evaluated in 2010 and 2011.

The local plant management was initially very interested in the green aspects of the project, but quickly perceived economic value in the project also. Due to changing production requirements associated with the falling price of natural gas, and the overall impacts of the economic recession and ongoing recovery, Dow management realized that the project could offer more than environmental benefits. Dow had excess steam about half the time, but was short steam the other half of the year. The ability to sell or take steam as needed from the project was of considerable economic value, as it simplified their boiler operation and provided economic value by averting their ongoing need to vent large amounts of steam. The project team pursued a number of different project variations and commercial structures with Dow. As time went on, however, the team was unable to close the commercial hurdles required by Dow to engage in the project.

\section{Chapter 4: Power Sale Only}

With the value of steam sales to both TOTAL and Dow markedly diminished, the project team also evaluated a straight-forward waste heat to power option. By enlarging the steam turbine such that all recovered energy could generate electricity, the project could potentially benefit from price differentials between natural gas and electricity. The project team evaluated opportunities to sell power to Clean Harbors and to the wholesale market in the Electric Reliability Council of Texas (ERCOT). Clean Harbors purchases power from the wholesale market, so nearly all electricity produced in the project would result in an average income of about $\$ 52$ per MWh. Spot market prices in ERCOT closely follow natural gas prices, as natural gas combined cycle power plants represent the marginal generators in Texas. In addition, spot prices encounter large fluctuations, especially at night, when the state's large installed base of wind generators is at maximum output. Nuclear and other must run power plants continue to operate also, causing a power glut that drives the wholesale price of power in ERCOT to near zero or below. As a result of low and variable rate for power produced by the project, the project team was not able to finance the project as an electricity only solution.

\section{Chapter 5: Engineer/Procure/Construct (EPC)}

The development team undertook significant engineering to fully estimate equipment and construction costs. This work resulted in a large number of drawings detailing major equipment required by the project. 


\section{$\boldsymbol{Y}|\mathbf{H}| \mathbf{A}|\mathbf{R}| \mathbf{C} \mid \boldsymbol{H}$}

Battleground Energy Recovery Project

Final Report

October 1, 2009 - December 31, 2011

\section{Chapter 6: Archeological Study}

Due to its proximity to the Battle of San Jacinto battlefield, the project required an archeological study be completed prior to construction. Moore Archeological Consulting of Houston, Texas was subcontracted to undertake the study. The study entailed a detailed survey of the proposed project area in the northwest corner of the Clean Harbors property and along the steam pipeline corridor to the adjacent Dow Chemical facility.

The study team issued its final report in July, 2011. In his final report, Douglas Mangum, the Principal Investigator on the study, wrote that no artifacts of either historic or prehistoric origin were found during the survey, including anything related to the Battle of San Jacinto. Mr. Mangum recommended that no further archeological investigations, including those involving metal detecting, be performed on the Clean Harbors property before the onset of construction. On August 11, 2011, the Texas Historical Commission issued a letter concurring with the recommendations in the report. As the final requirement needed to complete the NETL Environmental Audit (EA), submission of the final archeological study report and concurrence letter from the Texas Historical Commission, the EA for this project should also be complete.

\section{Chapter 7: Lessons Learned}

The project development spent three years developing the Battleground Energy Recovery Project at Clean Harbors in Deer Park, Texas. A number of valuable lessons were learned in the process.

\section{$\underline{\text { Capital Costs }}$}

Retrofitting waste heat recovery boilers into existing industrial facilities necessitates custom boiler designs and complex construction techniques. As a result, the capital costs of industrial waste heat recovery projects are high on a $\$ / \mathrm{kW}$ basis relative to utility-scale projects and vary according to the specifics of each site. Cost estimates are difficult to assess without substantial upfront engineering to evaluate equipment and construction approaches.

\section{Host Risks}

To accommodate construction and integration of the project onto the industrial site, the project host would have to shut down some portion of their revenue generating operations. As a result, the host will experience lost revenues and perceive numerous risks in restarting operations following completion of construction. In addition, integration of the boiler into the process stream necessitates opening the emissions permit to review by appropriate state and federal regulatory agencies. Consequently, projects of this type must offer excellent returns to the host to provide adequate incentive to take on the risks associated with the project.

\section{Commodity Pricing}

Like all energy, the energy captured in a waste heat recovery project is a commodity that must compete head to head with other energy supply options. Volatility in energy markets directly impact the viability of waste heat recovery projects. 


\section{$\underline{\text { Soft Cost Savings/Externalities }}$}

This project resulted in numerous soft cost savings to the host and others including for example, lower water softening costs, lower electricity consumption for water pumping, lower costs to maintain cooling towers, and lower cost to purchase water for the operation. Without exception, the host was not willing to assign a full economic value to these savings, thereby requiring the project economics to stand solely on the value of energy produced.

\section{Multiparty Contracting}

The development team experienced some minor difficulty allocating the benefits and risks inherent in the project equitably among the parties involved, and this somewhat became a deterrent to the project. Each corporate partner had different requirements regarding safety protocols, security, insurance, and indemnification, which somewhat increased the difficulty of the contracting process. Consequently, projects that offer excellent economics are needed to adequately provide for the added development costs and to ensure each party is sufficiently rewarded to attract them into the project.

\section{"Boutique" Financing Requirement}

With a total installed capital cost of approximately $\$ 28$ million, the equity financing requirement for the project was estimated at about $\$ 5.6$ million at an $80 \%$ debt level.

Placement of the equity was challenged by low energy prices and also the scale of the project relative to conventional utility-scale projects. "Boutique" financing options are available, but equity providers investing such small amounts are typically looking for even higher (than average) returns in order to justify their efforts on a small, one-off deal like the Battleground project. As a result, the project team found that Clean Harbors was really the only logical equity partner. Clean Harbors considered the equity investment, because:

- as host facility, the project would be highly integrated into their process

- $\quad$ some of the O\&M costs, such as labor and property taxes, could be rolled into their existing operational expenses

- they could capture soft cost savings associated with water treatment, pumping, and consumption.

Even with these benefits, the project did not provide sufficient returns to Clean Harbors to motivate an equity investment from them.

The project team learned that if projects do not generate stellar returns for investors, many waste heat recovery and combined heat and power projects of a size and scale similar to the Battleground Energy Recovery Project may also find difficulties in securing equity financing from both the project host facility and from $3^{\text {rd }}$ party investors.

\section{End of Report}

